\title{
Biological markers and severe head trauma. Where are we?
}

\author{
Leonardo Christiaan Welling', Vinicius Monteiro Paula Guirado², Glauce Damásio Costa ${ }^{3}$, \\ Eberval Gadelha Figueiredo4, Almir Ferreira de Andrade ${ }^{5}$, Manoel Jacobsen Teixeira ${ }^{6}$
}

Division of Neurosurgery. Bom Jesus Hospital. Ponta Grossa, PR, Brazil and Division of Neurosurgery Hospital das Clínicas, University of Sao Paulo, Sao Paulo, SP, Brazil.

\begin{abstract}
Traumatic brain injury (TBI) constitutes a major health and socioeconomic problem throughout the world. Despite the significant advances in neuroradiology and cerebral monitoring it is still difficult to measure the degree of primary brain injury and continuing secondary damage with Glasgow Coma Scale score or the initial computed tomography. Predicting prognosis of TBI patients in early stages has a vital importance and is difficult in some instances. The present review shows that there has been an increasing interest in biochemical markers for traumatic brain injury during the last years. The potential correlation of markers with injury and outcome measures in severe head injury is promising.
\end{abstract}

\section{KEYWORDS}

Biological markers, craniocerebral trauma, prognosis.

\section{RESUMO}

Marcadores biológicos e traumatismo craniano grave. Onde estamos?

O traumatismo cranioencefálico constitui um grave problema socioeconômico em todo o mundo. Apesar dos avanços em neurorradiologia e neuromonitorização, ainda é difícil mensurar a injúria primária e prever os danos secundários dos pacientes com base somente na Escala de Coma de Glasgow ou na tomografia de crânio da admissão. Predizer o prognóstico dos pacientes ainda em uma fase inicial é de vital importância, porém muitas vezes difícil. A presente revisão mostra que há interesse cada vez maior nos marcadores biológicos relacionados ao trauma de crânio. A potencial correlação dos biomarcadores da injúria primária com o desfecho dos pacientes com traumatismo craniano grave é promissora.

\section{PALAVRAS-CHAVE}

Marcadores biológicos, traumatismos craniocerebrais, prognóstico.

\section{Introduction}

Traumatic brain injury (TBI) constitutes a major health and socioeconomic problem throughout the world. Globally, TBI is a leading cause of death and disability in children and young adults. It is the primary cause of death in $30 \%-50 \%$ of all injury-related deaths. ${ }^{1-3}$

Despite the significant advances in cerebral monitoring, it is still difficult to measure the degree of primary brain injury and continuing secondary damage with Glasgow Coma Scale (GCS) score or the initial computed tomography (CT). Predicting prognosis of
TBI patients in early stages has a vital importance and is difficult in some instances. ${ }^{4-6}$

Attempts to predict clinical outcome or mortality using the admission GCS or CT-scan findings have not been as reliable as we would like. Petzold et al. ${ }^{7}$ found that the initial GCS of 3-8 predicted fatal outcome with a sensitivity of only $62 \%$. This is partially due to the use of intubation and intravenous sedation, anesthetics and neuromuscular blockade in the early resuscitation efforts. ${ }^{8}$ Consequently, increasing research is being devoted to the development of other tools to assess the severity of the initial brain injury, to identify

1. Neurosurgeon. Post-Graduation Program. University of Sao Paulo, Brazil.

2. Neurosurgeon. Neurosurgery Division of Hospital das Clínicas, University of Sao Paulo, Brazil.

3. Nurse. University of Ponta Grossa (UEPG). Pharmacy Student. Cescage. Ponta Grossa, Brazil.

4. Neurosurgeon. Head of Neurovascular Group and Supervisor of Division of Neurosurgery of Hospital das Clínicas, University of Sao Paulo, Brazil.

5. Neurosurgeon. Head of Neurotraumatology Group of Neurosurgery Division of Hospital das Clínicas, University of Sao Paulo, Brazil.

6. Neurosurgeon. Chairman. Division of Neurosurgery Hospital das Clínicas, University of Sao Paulo, Brazil. 
patients at high risk for mortality and morbidity, and to predict outcome. These challenges have created a need for biomarkers that reflect core elements of the disease process.

\section{Biomarkers}

Nowadays several specialties employ biomarker blood tests to diagnose, direct treatment, and prognosticate. The most common used biomarkers include troponin $\mathrm{T} / \mathrm{CK}-\mathrm{Mb}$ in cardiology, procalcitonin in sepsis, amylase and lipase in pancreatic disease. Regarding to a TBI biomarker this should show high specificity and sensitivity for brain, be released only after irreversible destruction of brain tissue, have a rapid appearance in serum, show low age- and sex-related variability, and have reliable assays for immediate analysis. ${ }^{9}$

There are many structural markers of brain injury that have been examined in TBI. These biomarkers reflect damage from each of the major cell types in brain parenchyma (astrocytes, neurons and axons) have been studied. ${ }^{9}$

They may be released in response to oxidative stress, inflammation, cerebral blood flow dysregulation, excitotoxicity, apoptosis and cell death..$^{10}$ Although several potential biomarkers have been assessed in the past, for the purposes of this review, we will focus on the markers of structural brain injury that have received the most attention in recent clinical series. These include S100B, neuron-specific enolase (NSE), myelin basic protein (MBP), and glial fibrillary acid protein (GFAP).

\section{S-100B}

S-100B protein belongs to a multigenic family of low molecular weight (9-13 kD) calcium-binding S100 proteins that is most abundant in glial cells of the central nervous system, predominantly in astrocytes. ${ }^{11}$ It is functionally involved in the regulation of cell morphology by interaction with elements of the cytoplasmatic cytoskeleton and is actively secreted from astroglia via an unknown mechanism. Its biological half-life is of $2 \mathrm{~h}$, not influenced by hemolysis, and remains stable even if samples are not centrifuged and frozen immediately. Protein S100B can be detected in both cerebrospinal fluid (CSF) and blood. Its concentration has been shown to increase in CSF and/or serum after a number of cerebral diseases, including traumatic brain injury, cerebral infarction, subarachnoid hemorrhage and parenchymal infections. ${ }^{12-17}$
The samples can be removed from arterial lines, but some investigators have advocated the use of jugular venous lines to measure S100B in an attempt to avoid mixing in fractions of S100B that arise from others sites. ${ }^{18}$ Some investigators have sampled S100B from CSF taken from external ventricular drains but, others have been concerned that S100B levels can be altered by ventricular catheter placement; thereby, confounding the specificity of the measurements in brain injury. ${ }^{19}$

The majority of the literature reported to date involves the elevation of S100B in patients who have sustained traumatic brain injury. Elevations in this protein have been reported to reflect injury to the brain and increased permeability of the blood brain barrier. Their levels reflect various consequences of severe brain injury such as swelling, contusions, and diffuse axonal injury. ${ }^{20}$

There are many investigations, which have reported that $\mathrm{S100B}$ serum level elevations reliably reflect severe brain injury and that the extent of S100B elevation can reliably predict functional outcomes and even potentially predict patient mortality. They uniformly have found that serum S100B levels were directly proportional to the severity of injury and inversely proportional to the Glasgow Outcome Score (GOS). Patients with poor outcomes (GOS 1-3) had significantly higher serum S100B levels than patients with better outcomes (GOS 4-5) with a $\mathrm{P}$ value of $<0.01$. Mean S100B levels ranged from $1.1 \mathrm{mcg} / \mathrm{l}$ to $4.9 \mathrm{mcg} / \mathrm{l}$ in patients with poor outcomes. Patients with better outcomes demonstrated significantly lower S100B levels ranging between $0.3 \mathrm{mcg} / \mathrm{l}$ and $1.6 \mathrm{mcg} / \mathrm{l}$. Corroborating these results serum S100B levels were found to be elevated more in patients who developed hypotension, hypoxia, or absent pupillary light reflexes, which are patients who had a worse outcome. . $^{9,18,21}$

According to Vos et al. ${ }^{16}$ the absolute level of S100B elevation during the first $24 \mathrm{~h}$ after injury might be a reliable predictor of mortality or clinical outcome despite the warnings of others workers. They reported on a series of 85 patients with severe head injury where the initial S100B levels accurately predicted mortality. They found that patients who died had a statistically significant higher initial serum $S 100 \mathrm{~B}$ level than patients who survived with a $\mathrm{P}$ value of $<0.001$.

The temporal pattern of biochemical markers measured over the ensuing days after the injury has been studied too. Dimopoulou et al. ${ }^{22}$ have reported an investigation of 47 patients with severe brain injury (GCS 3-8 after neurological resuscitation) where 17 developed the criteria for brain death. All patients underwent serial S100B measurements at the time of admission and every $24 \mathrm{~h}$ for 6 days. The median S100B level of patients progressing to brain death was $2.32 \mathrm{mcg} / \mathrm{l}$. Survivors had a statistically significant lower median S100B level at 1.04 $\mathrm{mcg} / \mathrm{l}(\mathrm{P}=0.0028)$. According to another study, Raabe 
et al. ${ }^{9}$ showed that secondary increases in S100B levels preceded increased ICP and neuroimaging findings in patients who subsequently developed secondary brain injury, which culminated in brain death.

So important as a reliable predictor of death and clinical outcome are these studies, which described sustained elevations of S100 in a temporal evaluation. This might reflect a significant original injury or ongoing secondary injury to the brain. These measurements might afford us the opportunity to identify patients in the early stages of secondary brain injury. ${ }^{9,18}$

It should be noted that the reliability of S100B as a measure of brain injury depends upon its specificity to brain tissue. There are many extracranial sources of S100B however muscle and adipose tissue are the most commons. ${ }^{23}$

In the clinical context sometimes is difficult to interpret the S100B elevations in patients with brain injury when variable amounts of skeletal muscle injury (polytraumas) can influence the elevations. The problem of S100B's lack of specificity to brain injury warrants considerations in the evaluation of patients with traumatic brain injury (TBI) and multiple organ lesions. ${ }^{24,25}$

Regarding to this, Savola et al. ${ }^{26}$ evaluated the relative contributions of different types of head and extracranial traumas on serum S100B levels in 379 consecutive trauma patients. In this series were included 54 patients with cranial and extracranial injuries as well as 155 patients with pure extracranial injuries. They measured S100B levels within $6 \mathrm{~h}$ of injury and then correlated to neurological examinations, injury severity score (ISS) and CT scan findings. They found that severe extracranial injuries without brain injury could significantly elevate S100B levels. However, the brain injury was associated with significantly higher levels of S100B. The median elevation of S100B from head trauma was $0.17 \mathrm{mcg} / \mathrm{l}$ while the median elevation of S100B from pure extracranial trauma was significantly lower at $0.07 \mathrm{mcg} / \mathrm{l}$ (with statistical significance). Besides these findings they confirmed that normal S100B levels were a very reliable predictor of good neurological outcome.

In a similar investigation, Pelinka et al. ${ }^{23,24}$ attempted to determine whether the measurement of S100B serum levels was a reliable marker for TBI in a series of patients with and without multiple organ traumas. All polytraumatized patients demonstrated elevated S100B levels whether or not TBI was present demonstrating that these levels were sensitive to injury outside of the brain too. In the same research the initial S100B levels were highest in non-survivors with TBI and multiple organ injury followed by survivors with TBI and multiple organ injury. Therefore, the S100B serum levels taken during the first $24 \mathrm{~h}$ did not reliably predict clinical outcome in this patient population. It was advocated the daily measurement of serum S100B markers as a reliable means of predicting clinical outcome. They observed that secondary $\mathrm{S} 100 \mathrm{~B}$ elevations could be used as a reliable marker for the development of secondary brain injury enabling intensivists to initiate clinical interventions at an earlier moment. ${ }^{25,27}$

Translating these results to clinical practice the best mode to differentiate between the $\mathrm{S} 100 \mathrm{~B}$ coming from the brain and the body is to look at serial S100B levels over a few days time. The release of S100B from injured skeletal muscle has been found to be short lived and back to normal levels within 20h. Elevations of S100B after $24 \mathrm{~h}$ may more reliably reflect brain injury as long as continued muscle injury is not occurring such as in compartment syndromes. ${ }^{23,25,27}$

Despite it is not studied yet, the efficacy of interventions could be monitored by following the response of the S100B levels and correlated to clinical outcome studies. It may offer a potential window of opportunity for earlier clinical intervention that may successfully mitigate the clinical impact of secondary brain injury and improve clinical outcomes.

\section{Neuron specific enolase}

NSE is a glycolytic enzyme with a molecular weight of $78 \mathrm{kDa}$ and a biological half-life of $48 \mathrm{~h}$. It is functionally active as a heterodimer assembled from alpha, beta and gama subunits. The gama-gama isoform is specific for neurons, while the alpha-gama isoform is specific for neuroendocrine cells. This protein is located in the neuronal cytoplasm and is involved in regulating intracellular chloride levels. ${ }^{15}$ Others researchers have found that NSE is also present in red blood cells and platelets, decreasing its diagnostic utility as a marker due to possible cross-contamination that could occur in blood samples. . $^{28-30}$

Serum levels above $7-10 \mathrm{mcg} / \mathrm{L}$ are considered abnormal NSE in serum. The peaks occur within $12 \mathrm{~h}$ after injury and decreases during the subsequent hours. Secondary increases of NSE have been seen in a few patients with poor or fatal outcomes. ${ }^{10,31,32}$ Statistically significant elevation was observed in serum (mean 12.8 $\mathrm{mcg} / \mathrm{l}$ ) and CSF (mean $7.8 \mathrm{mcg} / \mathrm{l}$ ) levels in patients after severe traumatic brain injury $(\mathrm{n}=51)$, but only CSF levels showed a correlation with GCS. ${ }^{33}$

Vos et al. ${ }^{16}$ have demonstrated that serum NSE levels were correlated significantly with the injury severity score and CT findings and were significantly higher in nonsurvivors (>21.7 $\mathrm{mcg} / \mathrm{l}$ ) and in patients with poor outcome 6 months postinjury. Another correlation between temporal serum NSE measurements and GCS and 3-month outcome has also been reported. The 
secondary increase in the marker was related with a secondary insult such as hypoxia or hypotension; which predicted unfavorable outcome. ${ }^{34}$

In clinical studies, serum NSE levels have been frequently studied alongside S-100B. Reports on correlations of serum NSE levels alone with clinical and neurological measures of brain injury magnitude and overall outcome have been controversial although assay of serum NSE together with S100B have been valuable in predicting TBI outcome. ${ }^{35,36}$

There is a close relationship between the serum NSE levels and GCS score in 2, 24, $48 \mathrm{~h}$ after TBI. It is shown that high values of serum NSE after brain injury are related to poor clinical outcome. Measurement of serum NSE levels may provide useful information about the course of the patients with TBI if it is added to clinical and radiological workups. If these results are confirmed by new large clinic studies, NSE could be used as a helpful screening tool for short-term outcome in TBI. ${ }^{23}$

However, like all biomarkers, NSE has limitations. NSE may be limited by the occurrence of false positives with hemolysis and extracranial sources. ${ }^{25}$ Some studies suggest that NSE has limited utility as a prognostic index in TBI since its diagnostic utility as a marker due to possible cross-contamination that could occur in blood samples. ${ }^{29,37}$

\section{Myelin basic protein}

One of the most essential structural proteins in the CNS is the Myelin Basic Protein (MBP), especially in the white matter. It is hypothesized that TBI-mediated axonal injury causes secondary structural damage to the adjacent myelin membrane, resulting in MBP degradation. This potentially could initiate myelin sheath instability and demyelination, which may further promote axonal vulnerability. ${ }^{38}$

Normal serum levels of MBP are very low, typically $0.3 \mathrm{ng} / \mathrm{ml}$ and high serum MBP levels were found to correlate with worse outcome after TBI. These appear to have good specificity but poor sensitivity for TBI. ${ }^{35}$ According to Berger et al. in a study involving pediatric TBI patients initial peak MBP concentrations in the serum had a specificity of $96 \%$ but sensitivity of only $44 \%$. Children with inflicted TBI had later peak concentrations of MBP, similar to that seen with NSE, and higher MPB levels on admission compared to patients with noninflicted TBI. ${ }^{35,36}$

Actually, regarding to this data in these specific population, the MBP may be useful in predicting outcome after pediatric TBI. ${ }^{36}$

\section{Glial fibrillary acidic protein}

Serum GFAP might be a useful marker for various types of brain damage in neurodegenerative disorders and in stroke. ${ }^{39}$ It is released into the extracellular space in the event of cell damage and is highly specific to the central nervous system. Such biomarker represents the major part of astroglial cytoskeleton. ${ }^{40}$ Animal experiments have demonstrated a time-dependent release of GFAP after severe cortical impact injury in rats. In these cases the highest levels were observed 1-hour after the trauma. ${ }^{10}$ According to Missler et al. ${ }^{40}$ pathological levels are those higher than $0.033 \mathrm{mcg} / \mathrm{l}$. Human studies shows that the highest levels of GFAP are observed in the first days after de TBI. There are studies correlating this biomarker with Marshall Classification of Cerebral CT scan. The GFAP was lower in Diffuse Injury II (cisterns present with midline shift of $0-0.5 \mathrm{~cm}$ and/ or no focal lesion of $>25 \mathrm{ml}$ ) than in Diffuse Injury IV (swelling, midline shift of $>0.5 \mathrm{~cm}$, no lesion of $>25$ $\mathrm{ml}$ ). Additionally, GFAP was lower in Diffuse Injury II than in nonevacuated mass lesions. It should be noted that GFAP levels are normal in polytrauma patients without TBI. ${ }^{25}$

\section{Discussion}

The present review shows that there has been an increasing interest in biochemical markers for traumatic brain injury during the last years. The potential correlation of markers with injury and outcome measures in severe head injury is promising.

The S-100B protein has been intensively investigated in severe head injury. Several papers found significant correlation unanimously between the marker and both the injury and the outcome. Therefore, multicenter investigation and the introduction of S-100B into the clinical routine should be considered with caution since the multiple organ traumas can also contribute to the higher serum levels.

Regarding to the others biomarkers (GFAP, NSE and $\mathrm{MBP}$ ), there are few studies, however they also show promising results.

It should be emphasized that the aim to find an ideal biomarker has proved difficult for several reasons. The brain is a hugely complex organ and is protected by a selective blood brain barrier. Its functions are both qualitative and quantitative, while most biomarkers are purely quantitative. For example, lobar injury has different consequences for outcome compared with the same volume of tissue injury in the brainstem. Furthermore, extracranial sources of the biomarker also may limit its 
specificity. The level of a biomarker in the serum may also reflect both the degree of cellular injury and/or the degree of blood brain barrier disruption. Finally, as in most aspects of TBI, there are many clinical variables and physiopathological factors that affect the patient outcome.

\section{Conclusion}

Several biomarkers of brain injury have been identified and continued research is required. In the future it may be possible to find biomarkers that accurately predict the temporal evolution of secondary damage or biomarkers that provide assistance in the establishment of diagnosis and outcome. Probably a single biomarker will not be able to accurately predict which patients are at risk for specific outcomes. Future studies will be necessary to develop a useful test in which a panel of TBI-associated biomarkers are evaluated and used to prompt treatment.

\section{References}

1. Cole TB. Global road safety crisis remedy sought: 1.2 million killed, 50 million injured annually. JAMA. 2004;291(21):2531-2.

2. Ghajar J. Traumatic brain injury. Lancet. 2000;356(9233): 923-9.

3. Sosin DM, Sniezek JE, Waxweiler RJ. Trends in death associated with traumatic brain injury, 1979 through 1992. Success and failure. JAMA. 1995;273(22):1778-80.

4. Balestreri M, Czosnyka M, Chatfield DA, Steiner LA, Schmidt EA, Smielewski $P$, et al. Predictive value of Glasgow Coma Scale after brain trauma: change in trend over the past ten years. J Neurol Neurosurg Psychiatry. 2004;75(1):161-2.

5. Formisano R, Carlesimo GA, Sabbadini M, Loasses $A$, Penta $F$, Vinicola $V$, et al. Clinical predictors and neuropsychological outcome in severe traumatic brain injury patients. Acta Neurochir (Wien). 2004;146(5):457-62.

6. Schaan M, Jaksche H, Boszczyk B. Predictors of outcome in head injury: proposal of a new scaling system. J Trauma. 2002;52(4):667-74.

7. Petzold A, Green AJ, Keir G, Fairley S, Kitchen N, Smith $M$, et al. Role of serum S100B as an early predictor of high intracranial pressure and mortality in brain injury: a pilot study. Crit Care Med. 2002;30(12):2705-10.

8. Zink BJ. Traumatic brain injury outcome: concepts for emergency care. Ann Emerg Med. 2001;37(3):318-32.

9. Raabe A, Grolms C, Seifert V. Serum markers of brain damage and outcome prediction in patients after severe head injury. Br J Neurosurg. 1999;13(1):56-9.

10. Woertgen C, Rothoerl RD, Wiesmann M, Missler U, Brawanski A. Glial and neuronal serum markers after controlled cortical impact injury in the rat. Acta Neurochir Suppl. 2002;81:205-7.
11. Heizmann CW, Fritz G, Schäfer BW. S100 proteins: structure, functions and pathology. Front Biosci. 2002;7:1356-68.

12. Townend W, Dibble C, Abid K, Vail A, Sherwood R, Lecky F. Rapid elimination of protein S-100B from serum after minor head trauma. J Neurotrauma. 2006;23(2):149-55.

13. Undén J, Christensson B, Bellner J, Alling C, Romner B. Serum S100B levels in patients with cerebral and extracerebral infectious disease. Scand $J$ Infect Dis. 2004;36(1):10-3.

14. Usui A, Kato K, Abe T, Murase M, Tanaka M, Takeuchi E. S-100ao protein in blood and urine during open-heart surgery. Clin Chem. 1989;35(9):1942-4.

15. Vinores SA, Herman MM, Rubinstein LJ, Marangos PJ. Electron microscopic localization of neuron-specific enolase in rat and mouse brain. J Histochem Cytochem. 1984;32(12):1295-302.

16. Vos PE, Lamers KJ, Hendriks JC, Van Haaren M, Beems $\mathrm{T}$, Zimmerman $\mathrm{C}$, et al. Glial and neuronal proteins in serum predict outcome after severe traumatic brain injury. Neurology. 2004;62(8):1303-10.

17. Wiesmann M, Missler U, Hagenström H, Gottmann D. S-100 protein plasma levels after aneurysmal subarachnoid haemorrhage. Acta Neurochir (Wien).1997;139(12):1155-60.

18. Raabe A, Menon DK, Gupta S, Czosnyka M, Pickard JD. Jugular venous and arterial concentrations of serum S-100B protein in patients with severe head injury: a pilot study. J Neurol Neurosurg Psychiatry. 1998;65(6):930-2.

19. Kruse A, Cesarini KG, Bach FW, Persson L. Increases of neuron-specific enolase, $\mathrm{S}-100$ protein, creatine kinase and creatine kinase BB isoenzyme in CSF following intraventricular catheter implantation. Acta Neurochir (Wien). 1991;110(3-4):106-9.

20. Zimmer DB, Cornwall EH, Landar A, Song W. The S100 protein family: history, function, and expression. Brain Res Bull. 1995;37(4):417-29.

21. Rothoerl RD, Woertgen C, Holzschuh M, Metz C, Brawanski A. S-100 serum levels after minor and major head injury. $J$ Trauma. 1998;45(4):765-7.

22. Dimopoulou I, Korfias S, Dafni U, Anthi A, Psachoulia C, Jullien G, et al. Protein S-100b serum levels in traumainduced brain death. Neurology. 2003;60(6):947-51.

23. Pelinka LE, Hertz H, Mauritz W, Harada N, Jafarmadar M, Albrecht $\mathrm{M}$, et al. Nonspecific increase of systemic neuronspecific enolase after trauma: clinical and experimental findings. Shock. 2005;24(2):119-23.

24. Pelinka LE, Jafarmadar M, Redl H, Bahrami S. Neuronspecific-enolase is increased in plasma after hemorrhagic shock and after bilateral femur fracture without traumatic brain injury in the rat. Shock. 2004;22(1):88-91.

25. Pelinka LE, Kroepfl A, Leixnering M, Buchinger W, Raabe A, Redl H. GFAP versus S100B in serum after traumatic brain injury: relationship to brain damage and outcome. J Neurotrauma. 2004;21(11):1553-61.

26. Savola O, Pyhtinen J, Leino TK, Siitonen S, Niemelä O, Hillbom M. Effects of head and extracranial injuries on serum protein S100B levels in trauma patients. J Trauma. 2004;56(6):1229-34.

27. Pelinka LE, Toegel E, Mauritz W, Redl H. Serum S 100 B: a marker of brain damage in traumatic brain injury with and without multiple trauma. Shock. 2003;19(3):195-200.

28. Fletcher L, Rider CC, Taylor CB. Enolase isoenzymes. III. Chromatographic and immunological characteristics of rat brain enolase. Biochim Biophys Acta. 1976;452(1):245-52.

29. Johnsson P, Blomquist $S$, Lührs $C$, Malmkvist G, Alling $\mathrm{C}$, Solem JO, et al. Neuron-specific enolase increases in plasma during and immediately after extracorporeal circulation. Ann Thorac Surg. 2000;69(3):750-4. 
30. Leviton A, Dammann O. Brain damage markers in children. Neurobiological and clinical aspects. Acta Paediatr. 2002;91(1):9-13.

31. Nygaard O, Langbakk B, Romner B. Neuron-specific enolase concentrations in serum and cerebrospinal fluid in patients with no previous history of neurological disorder. Scand J Clin Lab Invest. 1998;58(3):183-6.

32. Woertgen C, Rothoerl RD, Holzschuh M, Metz C, Brawanski A. Comparison of serial S-100 and NSE serum measurements after severe head injury. Acta Neurochir (Wien). 1997;139(12):1161-4.

33. Ross SA, Cunningham RT, Johnston CF, Rowlands BJ. Neuron-specific enolase as an aid to outcome prediction in head injury. Br J Neurosurg. 1996;10(5):471-6.

34. Sawauchi S, Taya K, Murakami S, Ishi T, Ohtsuka T, Kato $\mathrm{N}$, et al. [Serum S-100B protein and neuron-specific enolase after traumatic brain injury]. No Shinkei Geka. 2005;33(11):1073-80.

35. Berger RP, Adelson PD, Pierce MC, Dulani T, Cassidy LD, Kochanek PM. Serum neuron-specific enolase, S100B, and myelin basic protein concentrations after inflicted and noninflicted traumatic brain injury in children. J Neurosurg. 2005;103(1 Suppl):61-8.

36. Berger RP, Beers SR, Richichi R, Wiesman D, Adelson PD. Serum biomarker concentrations and outcome after pediatric traumatic brain injury. J Neurotrauma. 2007;24(12):1793-801.

37. Ramont L, Thoannes H, Volondat A, Chastang F, Millet MC, Maquart FX. Effects of hemolysis and storage condition on neuron-specific enolase (NSE) in cerebrospinal fluid and serum: implications in clinical practice. Clin Chem Lab Med. 2005;43(11):1215-7.

38. Liu MC, Akle V, Zheng W, Kitlen J, O'Steen B, Larner SF, et al. Extensive degradation of myelin basic protein isoforms by calpain following traumatic brain injury. $\mathrm{J}$ Neurochem. 2006;98(3):700-12.

39. Herrmann M, Vos P, Wunderlich MT, De Bruijn CH, Lamers KJ. Release of glial tissue-specific proteins after acute stroke: a comparative analysis of serum concentrations of protein S-100B and glial fibrillary acidic protein. Stroke. 2000;31(11):2670-7.

40. Missler U, Wiesmann M, Wittmann G, Magerkurth O, Hagenström $\mathrm{H}$. Measurement of glial fibrillary acidic protein in human blood: analytical method and preliminary clinical results. Clin Chem. 1999;45(1):138-41.

Correspondence address

Leonardo C. Welling

Rua Tiradentes, 976, sala 1, Centro

84010-190 - Ponta Grossa, PR, Brazil

E-mail: leonardowelling@yahoo.com.br 